\title{
Effect of seaweed extract on rice (Oryza sativa var. ADT53) productivity and soil fertility in Cauvery delta zone of Tamil Nadu, India
}

\section{P. Deepana*}

Department of Soil Science \& Agricultural Chemistry, Tamil Nadu Agricultural University, Coimbatore - 641003 (Tamil Nadu), India

\section{K. Sathiya Bama}

Department of Soil Science \& Agricultural Chemistry, Tamil Nadu Rice Research Institute, Aduthurai - 612101 (Tamil Nadu), India

\section{P. Santhy}

Department of Soil Science \& Agricultural Chemistry, Tamil Nadu Agricultural University, Coimbatore - 641003 (Tamil Nadu), India

\section{T. Sivasankari Devi}

Department of Agricultural Microbiology, Tamil Nadu Rice Research Institute, Aduthurai - 612101 (Tamil Nadur), India

*Corresponding author Email: deepanadp29@gmail.com

\section{Article Info}

https://doi.org/10.31018/ jans.v13i3.2906

Received: August 5, 2021

Revised: September 9, 2021

Accepted: September 13, 2021

\section{How to Cite}

Deepana, P. et al. (2021). Effect of seaweed extract on rice (Oryza sativa var. ADT53) productivity and soil fertility in Cauvery delta zone of Tamil Nadu, India. Journal of Applied and Natural Science, 13(3), 1111 - 1120. https://doi.org/10.31018/jans.v13i3.2906

\begin{abstract}
The monocropping of rice in the Deltaic zone deteriorates soil health and crop productivity. Seaweeds are marine resources easily available at negligible cost and also rich in bioactive compounds. A field experiment was conducted at Cauvery Delta zone of Tamil Nadu during summer season2021 to evaluate the bio-efficacy of Seaweed extract on growth, yield, and soil properties of rice, Oryza sativa var. ADT53. The experiment was framed in RBD comprising of 12 treatments viz., soil application of Seaweed extract(SWE) @ 12.5kg/ha, $25 \mathrm{~kg} / \mathrm{ha}, 37.5 \mathrm{~kg} / \mathrm{ha}$, foliar spraying of SWE gel \& liquid @ $0.5 \%$ twice at tillering and panicle initiation stages, a combination of soil application and foliar spray and fertilizer alone. Experimental findings revealed that the soil application of SWE @ 12.5kg/ha along with a foliar spray of seaweed liquid recorded higher plant height $(121.1 \mathrm{~cm})$,dry matter production $(11390 \mathrm{~kg} / \mathrm{ha})$,yield attributes viz., number of grains per panicle (166), panicle length $(21.8 \mathrm{~cm})$, thousand grain weight $(14.7 \mathrm{~g})$, number of productive tillers per $\mathrm{m}^{2}(275)$, grain yield $(5612 \mathrm{~kg} / \mathrm{ha}$ )and straw yield $(7829 \mathrm{~kg} / \mathrm{ha})$. However, The soil application of SWE @ 25kg/ha recorded higher soil available nutrients viz., N(260 kg/ha);P(42kg/ha); K(170kg/ha);Ca (27.7meq/100g); Mg(5.5meq/100g);S(18.2mg/kg);Zn (1.17ppm); Fe (33.82ppm); Cu(1.61ppm);Mn(18.97ppm).The study will help sustain rice productivity and soil fertility in the deltaic zone of Tamil Nadu. The soil application of seaweed extract @ $12.5 \mathrm{~kg} / \mathrm{ha}$ along with foliar spraying $(0.5 \%$ twice $)$ could be a promising option in the rice ecosystem.
\end{abstract}

Keywords: Crop productivity, Oryza sativa, Rice, Seaweed extract, Soil fertility

\section{INTRODUCTION}

Rice is the staple food for the whole world. In India,rice is an important food crop that occupies about 44 million ha, with average production and productivity of about 144.52 million tons (2020-21).VanBussel et al. (2015) shared that rice shares $52 \%$ of area and $46 \%$ of production in total cereals under cultivation \& production in India. In Tamil Nadu, the rice occupies an area of about 20 million ha, with an average production of nearly 70 80 lakh tonnes. Grassinin et al.(2015) reported that the Cauvery Delta region is the main rice cultivated zone of
Tamil Nadu, contributing $>50 \%$ cultivable area. In this deltaic zone, rice is cultivated continuously as monocropping leads to deteriorating soil health. To sustain soil health economically, judicious application of chemical fertilizers and organic sources is essential. Due to the limited organic sources, the farmers need alternate one to improve the soil quality. In this context, seaweed is an alternative organic source that could be cheaply available and rich in growth-promoting substances.

Raghunandan et al. (2019) reported that seaweeds are important marine algae with admirable qualities of being renewable, biodegradable,flexible, non-toxic and 
tenacious. In India, 700 species of marine algae were found in both tidal and deep-water regions of the Indian coast. Among that, 60 species were commercially important. The seaweeds (macroalgae) were classified into three categories: brown algae, red algae, and green algae based on their pigmentation. They are abundantly grown along the coastal reserves in many parts of India, viz., Tamil Nadu, Gujarat, Goa, Maharashtra, West Bengal \& Orissa. Mirparsa et al. (2016) reported that, in sunflower, the seaweeds are known to add major plant nutrients viz., N, P,K, Ca, Mg, S, and different micronutrients and trace elements which required for crop growth and development. Arioli et al. (2015) noted that these weeds spp. Kappaphycus alvarezii is one of the macroscopic marine creatures grown in an intertidal and subtidal area where photosynthetic light $0.1 \%$ is available. Further, seaweeds are rich in organic compounds viz., proteins, amino acids, fat, cellulose, hemicellulose, lignin, vitamins (Raghunandan et al., 2019). Many studies pertaining to plant growth-promoting effects of seaweed have been reported by Shimaa et al. (2016). In fact, the plant growth-promoting seaweed substances in Arabidopsis influence the biosynthetic pathways of phytohormones in plants (Jithesh et al., 2012) and a rich amount of auxin, gibberellins, cytokinins and antibiotics boost the growth and yield of soyabean (Mathur et al., 2015). Pacholczaket al.(2016) have proven that in nine bark stem cuttings (Physocarpusopulifolius), the seaweed was the novel source of antioxidants and plant hormones osmoprotectants, plant nutrients and also bioactive metabolites of pharmaceutical and industrial significance. Evenni et al. (2015) reported that the seaweed extract from the brown seaweed stimulated the seed germination, root development, increased nutrient uptake, resistance to fungi and bacteria.Nabtiet al. (2010) proved that, in wheat, the seaweed application achieves higher yields with better plant and soil health restoration under high salinity conditions. Sunarpi et al. (2011) reported that in rice, the utilization of seaweedbased products has reduced the doses of nitrogen, phosphorus and potassic fertilizers and also induced the seed germination and growth parameters strongly than chemical fertilizers in corn (Partani., 2013). Haider et al. (2012) noted that the foliar spraying of seaweed extract improved the protein content, total soluble solids and nitrogen content of potato tubers. Rathinapriya et al. (2020) reported that, in foxtail millet, the application of liquid seaweed extracts improved plant growth and yield attributes and enhanced soil quality. Hussain et al. (2021) reported that the foliar application of seaweed extract in tomato had improved the soil microbial communities, available nitrogen, and soil health. Maneaand Abbas (2018) suggested that in Broccolithe foliar application of seaweed extract enhanced the cabbage quality and quantity. So the seaweed is one of the most reliable organic materials, which could improve the crop yield and quality of the soil. Hence to study the influence of seaweed extract in the monocropping of rice, the present research was initiated with the rice (Oryza sativa)var. ADT 53 in Cauvery Delta Zone of Tamil Nadu.

\section{MATERIALS AND METHODS}

The present experimental study was conducted at the Tamil Nadu Rice Research Institute, Aduthurai, Thanjavur district, representing the Cauvery Delta Zone of Tamil Nadu during summer season 2021 with high yielding rice variety ADT 53 . The soil texture of the experiment site is clay loam belong to Vertisol (soil order). The experiment was laid out in Randomized Block Design (RBD) with twelve treatments and three replications. The treatments comprised of soil application, foliar spray of seaweed products and combinations as mentioned in Table 1. All the treatments received an equal amount of recommended dose of fertilizer. As per the STCR (Soil Test Crop Response) recommendation,the entire dose of phosphorus $(76 \mathrm{~kg} / \mathrm{ha})$ was applied as basal and the remaining $\mathrm{N} \& \mathrm{~K}$ were applied as the split application of about $165 \mathrm{~kg} / \mathrm{ha}$ and $70 \mathrm{~kg} / \mathrm{ha}$ respectively. The observations viz., the plant height, dry matter production (DMP), Leaf Area Index (LAI), SPAD reading, root volume and root length in each plot at the interval of 30,60, 90 DAS and harvest were taken from randomly five plants. The yield parameters viz., no grains/panicles, no productive tillers/m2, thousand grain weight, panicle length were recorded at the harvesting stage from randomly 25 hills in each plot. The post-harvest data on grain yield, straw yield and harvest index were recorded and statistically analyzed using AGRES. The post-harvest soil samples were collected and analyzed for the soil fertility parameters-the initial soil parameters arere depicted in Table 2. The

Table 1. Treatment schedule for field experiments at Cauvery Delta zone

\begin{tabular}{ll}
\hline $\mathrm{T}_{1}$ & SWE gel soil application $12.5 \mathrm{~kg} / \mathrm{ha}$ \\
$\mathrm{T}_{2}$ & SWE gel soil application $25 \mathrm{~kg} / \mathrm{ha}$ \\
$\mathrm{T}_{3}$ & SWE gel soil application $37.5 \mathrm{~kg} / \mathrm{ha}$ \\
& Foliar spraying of SWE gel $0.5 \mathrm{per}$ cent $(\mathrm{v} / \mathrm{v})$ at \\
$\mathrm{T}_{4}$ & tillering + Panicle initiation stage \\
& $\quad$ Foliar spraying of SWE liquid 0.5 per cent $(\mathrm{v} / \mathrm{v})$ at \\
$\mathrm{T}_{5}$ & tillering + Panicle initiation stage \\
$\mathrm{T}_{6}$ & SWE gel soil application $12.5 \mathrm{~kg} / \mathrm{ha}+\mathrm{T}_{4}$ \\
$\mathrm{~T}_{7}$ & SWE gel soil application $25 \mathrm{~kg} / \mathrm{ha}+\mathrm{T}_{4}$ \\
$\mathrm{~T}_{8}$ & SWE gel soil application $37.5 \mathrm{~kg} / \mathrm{ha}+\mathrm{T}_{4}$ \\
$\mathrm{~T}_{9}$ & SWE gel soil application $12.5 \mathrm{~kg} / \mathrm{ha}+\mathrm{T}_{5}$ \\
$\mathrm{~T}_{10}$ & SWE gel soil application $25 \mathrm{~kg} / \mathrm{ha}+\mathrm{T}_{5}$ \\
$\mathrm{~T}_{11}$ & SWE gel soil application $37.5 \mathrm{~kg} / \mathrm{ha}+\mathrm{T}_{5}$ \\
$\mathrm{~T}_{12}$ & Control (fertilizer alone) \\
\hline
\end{tabular}


soil characteristics were estimated by using standard analytical methods viz., Organic carbon by Chromic acid wet digestion (Walkey and Black 1934), available Nitrogen by alkaline permanganate method (Subbiah and Asija 1956), available phosphorus by $0.5 \mathrm{NaHCO}_{3}$ (pH-8.5) (Olsen 1954), available potassium by Neutral Normal Ammonium Acetate Method (Stanford and English 1949), Exchangeable calcium and magnesium by Neutral Ammonium Acetate $(\mathrm{pH}-7.0)$, available sulphur by $0.15 \% \mathrm{CaCl}_{2}$ (Chesnin and Yien 1950) and available Micronutrients viz., $\mathrm{Fe}, \mathrm{Zn}, \mathrm{Cu}$ and $\mathrm{Mn}$ (Lindsay and Norvell 1979).

\section{RESULTS AND DISCUSSION}

In rice (Oryza sativa) var. ADT 53, the plant growth and yield attributes as well as soil properties were highly influenced by both soil and foliar application of seaweed extract.

\section{Effect of seaweed extract on growth parameters of rice}

The seaweed application highly influenced the plant growth parameters. Higher plant height is depicted at $\mathrm{T}_{9}$ (soil application of SWE @ $12.5 \mathrm{~kg} / \mathrm{ha}$ + foliar application of SWE liquid @ $0.5 \%$ ) of $46.4 \mathrm{~cm}$ which was on par with $T_{8}(41.8 \mathrm{~cm})$ and $T_{7}(42.3 \mathrm{~cm})$ and the lowest plant height was recorded in $T_{12}(32.6 \mathrm{~cm})$ in 30 DAS. The same trend of results was observed in 60 DAS and90DAS(Table 3). The increased plant height in $\mathrm{T}_{9}$ might be due to plant hormones, plant growth regulators like auxin, gibberellins, cytokinin, macro and microelements in the SWE, which elicit the strong physiological response at a low dose of concentration. The results are in line with Pramanicket al. (2013) who reported that the foliar application of $15 \%$ seaweed extract in
Table 2. Initial soil parameters of the experimental site at Cauvery delta zone of Tamil Nadu

\begin{tabular}{ll}
\hline organic carbon content $(\%)$ & $0.6 \%$ \\
$\mathrm{pH}$ & 7.4 \\
$\mathrm{EC}\left(\mathrm{dsm}^{-1}\right)$ & $0.47 \mathrm{dsm}^{-1}$ \\
available $\mathrm{N}(\mathrm{kg} / \mathrm{ha})$ & $243 \mathrm{~kg} / \mathrm{ha}$ \\
available $\mathrm{P}(\mathrm{kg} / \mathrm{ha})$ & $47 \mathrm{~kg} / \mathrm{ha}$ \\
available $\mathrm{K}(\mathrm{kg} / \mathrm{ha})$ & $170 \mathrm{~kg} / \mathrm{ha}$ \\
Exchangeable $\mathrm{Ca}(\mathrm{meq} / 100 \mathrm{~g})$ & $12.3 \mathrm{meq} / 100 \mathrm{~g}$ \\
Exchangeable $\mathrm{Mg}(\mathrm{meq} / 100 \mathrm{~g})$ & $2.4 \mathrm{meq} / 100 \mathrm{~g}$ \\
available Sulphur $(\mathrm{mg} / \mathrm{kg})$ & $8.8 \mathrm{mg} / \mathrm{kg}$ \\
available $\mathrm{Fe}(\mathrm{ppm})$ & $31.85 \mathrm{ppm}$ \\
available $\mathrm{Zn}(\mathrm{ppm})$ & $0.80 \mathrm{ppm}$ \\
available $\mathrm{Cu}(\mathrm{ppm})$ & $1.74 \mathrm{ppm}$ \\
available $\mathrm{Mn}(\mathrm{ppm})$ & $22.16 \mathrm{ppm}$ \\
\hline
\end{tabular}

green gram improved the crop quality and nutrient uptake (N,P, K and micronutrients). Dilavarnaiket al. (2017)also reported that in hybrid maize the foliar application of seaweed at $15 \%$ concentration either Kapp aphycusalvareziii (K sap) or Gracilaria edulis (Gsap) significantly improved the cell wall plasticity, apical dominance, meristematic growth and translocation of photo synthetase.

Leaf Area Index (LAI) was recorded higher under$T_{9}$ were 2.5, 6.6and8.5, which was on par with $\mathrm{T}_{10}$ (2.4, 6.4and8.4)and the least LAI was recorded in $T_{4}$, which was on par with $T_{5}(1.6,5.6$ and 7.7$)$ and $T_{12}(1.5$, 5.5and 7.2) at 30 DAS, 60 DAS and 90 DAS (Table 3). The increased LAI might be due to the presence of bioactive substances present in the SWE, which could

Table 3. Influence of seaweed extract on plant height and LAI of rice

\begin{tabular}{lllllll}
\hline & \multicolumn{5}{c}{ Plant height $(\mathbf{c m})$} & \multicolumn{2}{c}{ LAl } \\
\cline { 2 - 7 } Treatments & 30 DAS & 60 DAS & 90 DAS & 30 DAS & 60 DAS & 90 DAS \\
\hline $\mathrm{T}_{1}$ & 37.4 & 59.3 & 82.6 & 2.1 & 5.8 & 8.2 \\
$\mathrm{~T}_{2}$ & 36.1 & 57.9 & 80.7 & 1.9 & 5.7 & 7.9 \\
$\mathrm{~T}_{3}$ & 35.5 & 56.8 & 78.8 & 1.8 & 5.7 & 7.7 \\
$\mathrm{~T}_{4}$ & 32.8 & 50.9 & 72.4 & 1.6 & 5.5 & 7.4 \\
$\mathrm{~T}_{5}$ & 33.6 & 53.4 & 75.2 & 1.6 & 5.6 & 7.7 \\
$\mathrm{~T}_{6}$ & 42.7 & 63.4 & 87.4 & 2.3 & 6.2 & 8.3 \\
$\mathrm{~T}_{7}$ & 42.3 & 62.6 & 86.3 & 2.2 & 6.1 & 8.3 \\
$\mathrm{~T}_{8}$ & 41.8 & 62.0 & 85.2 & 2.1 & 5.9 & 8.2 \\
$\mathrm{~T}_{9}$ & 46.4 & 68.6 & 92.9 & 2.5 & 6.6 & 8.5 \\
$\mathrm{~T}_{10}$ & 45.4 & 67.4 & 91.4 & 2.4 & 6.4 & 8.4 \\
$\mathrm{~T}_{11}$ & 44.5 & 66.0 & 90.1 & 2.3 & 6.4 & 8.4 \\
$\mathrm{~T}_{12}$ & 32.6 & 47.7 & 71.3 & 1.5 & 5.5 & 7.2 \\
Sed & 1.2 & 1.5 & 2.4 & 0.1 & 0.1 & 0.2 \\
$\mathrm{CD}(\mathrm{P}=0.05)$ & 2.4 & 3.2 & 4.8 & 0.2 & 0.3 & 0.3 \\
\hline
\end{tabular}


have improved the stomatal uptake efficiency. Similar findings were reported by Rathore et al.(2009)in soybean that the foliar spraying of $15 \%$ seaweed extract could have enhanced the leaf area index, stomatal efficiency, and improved yield.

The higher value of SPAD reading was also recorded in $\mathrm{T}_{9}$ (44.8) followed by $\mathrm{T}_{10}$ (43.2) and $\mathrm{T}_{11}$ (42.8). The lowest SPAD reading was revealed in $T_{12}$ (37.3)in 30 DAS. A similar trend of results was also observed in 60 DAS and 90 DAS (Table 4). The higher SPAD value in $T_{9}$ might be due to plant growth stimulating substances like betaines and inorganic salts that might have increased the chloroplast size, granular development and chlorophyll concentration in the leaf surface. Similar results were reported by Whaphamet al. (1993) that, in cucumber cotyledons, the low concentration of betaines in seaweed extract has incrementally increased the SPAD reading at flowering stage and later it declined due to the development of fibrous material in plant tissues. The result on DMP showed that a high value was recorded under $T_{9}(4374 \mathrm{~kg} / \mathrm{ha})$, which was followed by $\mathrm{T}_{10}(4197 \mathrm{~kg} / \mathrm{ha})$ and it was on par with $\mathrm{T}_{11}(4081 \mathrm{~kg} /$ ha)and the lower values was recorded under $\mathrm{T}_{4}(3422$ $\mathrm{kg} / \mathrm{ha})$ and $\mathrm{T}_{12}(3350 \mathrm{~kg} / \mathrm{ha})$ at 30 DAS. The same trend of results was also observed in 60 DAS and 90 DAS (Table 4). Compared with the other treatments, $\mathrm{T}_{9}$ showed better improvement over the control due to the presence of growth-promoting substances and photo synthase in seaweed might lead to the upliftment of DMP. Pramanicket al. (2017)also suggested that in potato tubers, the foliar application of Kappaphycus sap with the concentration of $7.5 \%$ along with $100 \%$ RDF recorded higher dry matter production, crop yield and quality of potato. Similar results werealso reported by Rayorath et al. (2008) in barley, who reported that the lower dose of SWE at $15 \%$ concentration would im- prove the nutrient mobilization, partitioning, development of vigorous root system and enhancing the plant height, leaf area index, chlorophyll content.

\section{Effect of seaweed extract on root length and volume of rice}

The root length and root volume were also enhanced by SWE application (Table 5). The treatment $\mathrm{T}_{9}$ achieved higher root length on 30 DAS, 60 DAS and 90 DAS $(18.9 \mathrm{~cm}, 23.8 \mathrm{~cm}$ and $25.9 \mathrm{~cm})$ and statistically on par with $\mathrm{T}_{10}(18.2 \mathrm{~cm}, 23.2 \mathrm{cmand} 25.5 \mathrm{~cm})$ and $\mathrm{T}_{11}(17.4 \mathrm{~cm}$, $23 \mathrm{~cm}$ and $24.7 \mathrm{~cm}$ ) and lowest value was recorded in $\mathrm{T}_{12}(14.7 \mathrm{~cm}, 18.2 \mathrm{~cm}$ and $21.5 \mathrm{~cm})$ (Table 5).

Similar findings were also reported by Kumar et al. (2020) that in paddy, the RDF along with two times SoliGroGr (Ascophyllum nodosum) @ 10kg/ha improved the nutrient uptake by roots, water and nutrient use efficiency as well as enhanced the plant growth, root development and vigour of the plant. In the present study, the treatment $\mathrm{T}_{9}$ had registered higher root volume $(17.5 \mathrm{ml})$, which was statistically on par with $T_{10}$ $(17.1 \mathrm{ml})$ and $T_{11}(16.4 \mathrm{ml})$ and the lowest value was recorded under $\mathrm{T}_{12}(11.4 \mathrm{ml})$ on 30 DAS. A similar trend of results was also observed in 60 DAS and 90DAS (Table 5). Rayorath et al. (2008)also reported that in Arabidopsis leaves, the foliar application of seaweed extract at very low concentration improved the root growth and volume, which would have stimulated the cell division of root cells and produced more lateral root growth and root biomass. Selvaraj et al. (2004) reported that in Okra the foliar application of liquid seaweed fertilizer @ 2.5\% enhancing the microbial diversity and nutrient mobilization and mineralization. Dogra et al. (2012) reported that in onion, the soil application of seaweed granules @ 2.5g/ $\mathrm{m}^{2}$ recorded maximum shoot height and number of shoot per plant and lowest dis-

Table 4. Influence of seaweed extract on dry matter production and SPAD of rice

\begin{tabular}{lllllll}
\hline & \multicolumn{3}{c}{ DMP (kg/ha) } & & SPAD \\
\cline { 2 - 6 } Treatments & 30 DAS & 60 DAS & 90 DAS & 30 DAS & 60 DAS & 90 DAS \\
\hline $\mathrm{T}_{1}$ & 3588 & 5211 & 7605 & 41.2 & 41.1 & 30.7 \\
$\mathrm{~T}_{2}$ & 3520 & 5104 & 7559 & 40.7 & 40.8 & 30.5 \\
$\mathrm{~T}_{3}$ & 3505 & 4911 & 7442 & 39.8 & 39.6 & 29.3 \\
$\mathrm{~T}_{4}$ & 3422 & 4668 & 7295 & 39.1 & 38.7 & 26.4 \\
$\mathrm{~T}_{5}$ & 3459 & 4864 & 7363 & 39.2 & 39.2 & 28.9 \\
$\mathrm{~T}_{6}$ & 3930 & 5365 & 8146 & 42.3 & 42.1 & 32.8 \\
$\mathrm{~T}_{7}$ & 3790 & 5314 & 7971 & 42.1 & 41.7 & 32.2 \\
$\mathrm{~T}_{8}$ & 3698 & 5263 & 7881 & 41.6 & 41.3 & 31.3 \\
$\mathrm{~T}_{9}$ & 4374 & 5667 & 8437 & 44.8 & 44.0 & 34.8 \\
$\mathrm{~T}_{10}$ & 4197 & 5574 & 8354 & 43.2 & 42.7 & 33.5 \\
$\mathrm{~T}_{11}$ & 4081 & 5459 & 8224 & 42.8 & 42.3 & 33.4 \\
$\mathrm{~T}_{12}$ & 3350 & 4592 & 7123 & 37.3 & 37.5 & 24.1 \\
Sed & 105 & 105 & 96 & 0.6 & 0.9 & 0.8 \\
$\mathrm{CD}(\mathrm{P}=0.05)$ & 219 & 217 & 199 & 1.2 & 1.9 & 1.7 \\
\hline
\end{tabular}


Deepana, P. et al. / J. Appl. \& Nat. Sci. 13(3), 1111 - 1120 (2021)

Table 5. Influence of seaweed extract on root length and root volume of rice

\begin{tabular}{lllllll}
\hline & \multicolumn{2}{c}{ 30 DAS } & \multicolumn{2}{c}{ 60 DAS } & \multicolumn{2}{c}{ DAS } \\
\cline { 2 - 7 } Treatments & $\begin{array}{l}\text { Root Volume } \\
(\mathbf{m l})\end{array}$ & $\begin{array}{l}\text { Root length } \\
(\mathbf{c m})\end{array}$ & $\begin{array}{l}\text { Root Volume } \\
(\mathbf{m l})\end{array}$ & $\begin{array}{l}\text { Root length } \\
(\mathbf{c m})\end{array}$ & $\begin{array}{l}\text { Root Volume } \\
(\mathbf{m l})\end{array}$ & $\begin{array}{l}\text { Root length } \\
\text { (cm) }\end{array}$ \\
\hline $\mathrm{T}_{1}$ & 14.4 & 15.6 & 22.3 & 20.9 & 29.2 & 23.1 \\
$\mathrm{~T}_{2}$ & 13.5 & 14.7 & 21.9 & 20.3 & 28.1 & 22.8 \\
$\mathrm{~T}_{3}$ & 13.2 & 14.5 & 20.6 & 19.9 & 27.7 & 22.2 \\
$\mathrm{~T}_{4}$ & 11.5 & 14.9 & 18.5 & 19.1 & 26.2 & 20.5 \\
$\mathrm{~T}_{5}$ & 12.4 & 14.8 & 19.1 & 18.9 & 27.2 & 21.3 \\
$\mathrm{~T}_{6}$ & 15.9 & 16.8 & 23.5 & 22.7 & 33.3 & 24.3 \\
$\mathrm{~T}_{7}$ & 15.0 & 16.4 & 23.0 & 22.0 & 32.2 & 23.9 \\
$\mathrm{~T}_{8}$ & 14.8 & 16.4 & 22.7 & 21.8 & 30.5 & 23.5 \\
$\mathrm{~T}_{9}$ & 17.5 & 18.9 & 25.6 & 23.8 & 36.6 & 25.9 \\
$\mathrm{~T}_{10}$ & 17.1 & 18.2 & 24.9 & 23.2 & 35.9 & 25.5 \\
$\mathrm{~T}_{11}$ & 16.4 & 17.4 & 23.7 & 23.0 & 34.3 & 24.7 \\
$\mathrm{~T}_{12}$ & 11.4 & 14.7 & 18.4 & 18.2 & 26.9 & 21.5 \\
Sed & 0.8 & 1.1 & 1.5 & 1.8 & 1.7 & 1.4 \\
$\mathrm{CD}(\mathrm{P}=0.05)$ & 1.8 & 2.3 & 3.2 & 3.7 & 3.6 & 2.8 \\
\hline
\end{tabular}

Table 6. Influence of seaweed extract on yield parameters of rice

\begin{tabular}{|c|c|c|c|c|c|}
\hline \multirow[b]{2}{*}{ Treatments } & \multicolumn{5}{|c|}{ Harvest stage } \\
\hline & $\begin{array}{l}1000 \text { grain } \\
\text { weight }(g)\end{array}$ & $\begin{array}{l}\text { Panicle length } \\
(\mathrm{cm})\end{array}$ & $\begin{array}{l}\text { No of grains/panicle } \\
\text { (Nos) }\end{array}$ & $\begin{array}{l}\text { No of productive tillers/ } \\
\mathrm{m}^{2} \text { (Nos) }\end{array}$ & $\begin{array}{l}\text { Harvest } \\
\text { Index (HI) }\end{array}$ \\
\hline $\mathrm{T}_{1}$ & 14.6 & 18.4 & 155 & 239 & 44.0 \\
\hline $\mathrm{T}_{2}$ & 14.6 & 18.1 & 153 & 232 & 43.7 \\
\hline $\mathrm{T}_{3}$ & 14.5 & 18.8 & 152 & 230 & 43.5 \\
\hline $\mathrm{T}_{4}$ & 14.6 & 18.4 & 147 & 223 & 42.4 \\
\hline $\mathrm{T}_{5}$ & 14.5 & 18.6 & 148 & 225 & 42.6 \\
\hline $\mathrm{T}_{6}$ & 14.6 & 19.6 & 159 & 252 & 42.5 \\
\hline $\mathrm{T}_{7}$ & 14.6 & 19.2 & 158 & 246 & 42.3 \\
\hline $\mathrm{T}_{8}$ & 14.6 & 19.5 & 156 & 239 & 41.3 \\
\hline $\mathrm{T}_{9}$ & 14.7 & 21.8 & 166 & 275 & 42.0 \\
\hline $\mathrm{T}_{10}$ & 14.6 & 21.5 & 164 & 269 & 42.0 \\
\hline $\mathrm{T}_{11}$ & 14.6 & 21.3 & 162 & 260 & 42.2 \\
\hline $\mathrm{T}_{12}$ & 14.5 & 18.3 & 145 & 220 & 41.7 \\
\hline SEd & NS & 1.0 & 2.8 & 8.4 & 0.5 \\
\hline$C D(P=0.05)$ & NS & 2.1 & 5.9 & 17.5 & 1.0 \\
\hline
\end{tabular}

ease severity. Selvaraj et al. (2004) reported that in Abelmoschus esculentus, the application of seaweed liquid fertilizer improved the growth and yield parameters.

\section{Effect of seaweed extract on yield attributes of rice}

Total yield may appraise to be the mirror of all the growth and yield features. Higher yield attributes were recorded under $T_{9}$ (soil application of SWE @ 12.5 kg/ ha + Foliar spraying of SWE liquid @ 0.5\%) viz, no of grains/ panicle - 166, panicle length $-21.8 \mathrm{~cm}$, no of productive tillers $\mathrm{m}^{-2}-275$ which was on par with $T_{10}$ (no of grains/ panicle - 164, panicle length $-21.5 \mathrm{~cm}$, no of productive tillers $\mathrm{m}^{-2}-269$ ) and $\mathrm{T}_{11}$ (no of grains/ panicle
- 162, panicle length $-21.3 \mathrm{~cm}$, no of productive tillers $\mathrm{m}^{-2}-260$ ). The lowest value was recorded under $T_{12}$ (no of grains/ panicle - 145 , panicle length $-18.3 \mathrm{~cm}$, no of productive tillers $\mathrm{m}^{-2}-220$ ), which was on par with $T_{4}$ (no of grains/ panicle - 147, panicle length $-18.4 \mathrm{~cm}$, no of productive tillers $\mathrm{m}^{-2}-223$ )and $T_{5}$ (no of grains/ panicle -148 , panicle length- $18.6 \mathrm{~cm}$, no of productive tillers $\mathrm{m}^{-2}-225$ )(Table 6 ). The higher yield attributes in $T_{9}$ might be due to the presence of bio-stimulant, which energizes the chlorophyll production, photosynthetic process, and thereby boosting vegetative growth. The results matched with Ishwarya et al. (2019), who observed that in green gram, the seed soaking in $0.1 \%$ 
seaweed extract solution for 30 minutes along with the foliar application of seaweed extract $0.25 \%$ twice increased the plant height, root volume, number of branches significantly. Singh et al. (2015) reported that the rice fertilized with $100 \%$ RDF produced higher productive tillers, number of grains per panicle, panicle length resulting in higher grain and straw yield in rice.

Regarding the grain yield and straw yield in the present study, treatment $T_{9}$ revealed the highest grain yield ( $5612 \mathrm{~kg} / \mathrm{ha}$ ), which was on par with $\mathrm{T}_{10}(5588 \mathrm{~kg} / \mathrm{ha}$ ) and $\mathrm{T}_{11}(5471 \mathrm{~kg} / \mathrm{ha})$. The lowest grain yield was recorded under $T_{12}(4645 \mathrm{~kg} / \mathrm{ha})$, which was on par with $T_{4}$ (4790kg/ha) (Fig.1). The treatment $T_{9}$ recorded a higher straw yield (7829 kg/ha) which was on par with $T_{10}$ $(7691 \mathrm{~kg} / \mathrm{ha})$ and the lowest straw yield was recorded under $\mathrm{T}_{12}(6492 \mathrm{~kg} / \mathrm{ha})$, which was on par with $\mathrm{T}_{4}$ $(6501 \mathrm{~kg} / \mathrm{ha})$ and $T_{5}(6543 \mathrm{~kg} / \mathrm{ha})$ (Fig. 2). The percent increase of grain yield and straw yield in $T_{9}$ was 18 $20 \%$ over the recommended dose of fertilizer alone. The increased yield might be due to readily available nutrients like $\mathrm{N}, \mathrm{P}, \mathrm{K}$, and trace mineral elements in the seaweed. The similar results were reported by Nayak et al.(2020) that in rice, the application of $75 \%$ RDF + Amaze-x granule @ 10kg/ha + Proventus DS legacy spray @ 625ml/ha observed higher panicle length, the number of filled grains per panicle resulting higher grain and straw yield. The positive influence of seaweed extract as biostimulant in aerobic rice enhanced crops' growth and yield, as reported by Anil et al. (2014). Leindahet al.(2015) also noted that the spraying of seaweed extract on the foliage of rice @ 15\% K sap with $100 \%$ RDF recorded higher growth and yield parameters viz., no of productive tillers/hill, panicle length, test weight, grain yield and straw yield. It was found that yield of grain was increased significantly by $11.80 \%$ over the control (100\% RDF).Pal et al. (2015) reported that in maize, the foliar application of seaweed extract @ 15\% Gracilaria(G sap) along with RDF observed higher growth parameters, yield attributes viz., cob length, no of grain per row, green cob yield and fodder

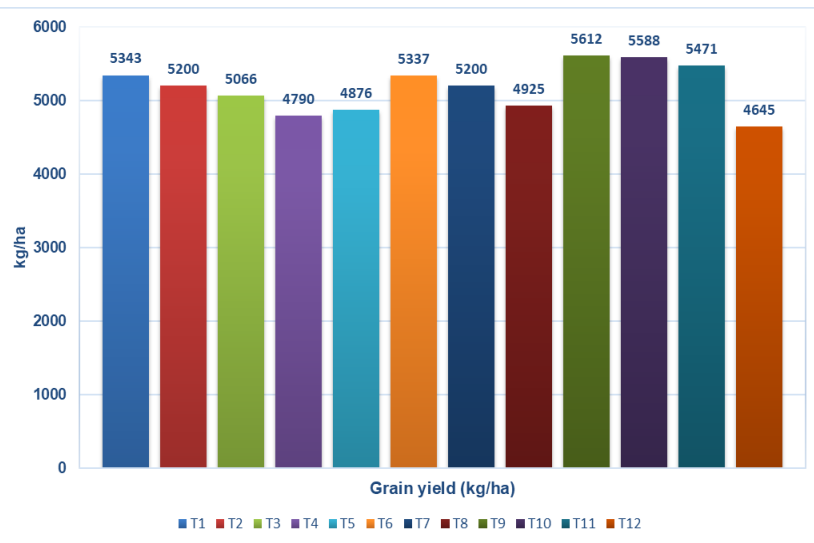

Fig 1. Grain yield in respective treatments expressed in kgha $^{-1}$ yield. The results are in line with Dwivedi et al. (2014), who proved that in Blackgram, the foliar application of $15 \%$ Kappaphycus sap and RDF resulted in an increase by $49.2 \%$ grain yield compared to RDF to control (water spray+ RDF). Arun et al.(2019) reported that in rice under the transplanted condition, the application of liquid bio-stimulant LBS6_S obtained higher yield attributes due to effective utilization of native as well as applied nutrients. Deshmukh et al. (2013) also showed that applying seaweed extract @ 1500 g/ha in sugarcane and RDF increased cane yield by $14 \%$ and sugar yield by $23.1 \%$.

\section{Effect of seaweed extract on soil properties of rice}

The results obtained from the post-harvest soil analysis are depicted in Table 7.There is no significant difference in $\mathrm{pH}$ and ECvalues after applying SWE. Cation exchange capacity (CEC) and organic carbon determined the nutrient status of the soil fertility. High value of Cation exchange capacity was reported under $\mathrm{T}_{2}$ (39.7 c mol (+) $\mathrm{kg}^{-1}$ ) followed by $\mathrm{T}_{1}\left(37.6 \mathrm{c} \mathrm{mol}(+) \mathrm{kg}^{-1}\right)$ and the lowest value was recorded under $\mathrm{T}_{12}(27.2 \mathrm{c}$ mol (+) $\left.\mathrm{kg}^{-1}\right)$, which was on par with $\mathrm{T}_{4}(27.7 \mathrm{c} \mathrm{mol}(+)$ $\left.\mathrm{kg}^{-1}\right)$. Organic carbon was reported higher under $\mathrm{T}_{2}$ $(0.96 \%)$ followed by $T_{1}(0.90 \%)$ and the lowest value was recorded under $\mathrm{T}_{12}(0.53 \%)$, which was on par with $\mathrm{T}_{4}(0.55 \%)($ Table 7$)$. The higher Cation Exchange capacity and Organic carbon in $\mathrm{T}_{2}$ might be due to the slow decomposition rate of soil carbon in rice cultivation and the highest carbon stock in seaweed. Dominguez et al. (2014) reported that the seaweed extracts in tomatoes restore plant growth in high $\mathrm{pH}$ and temperate conditions and Arthur et al. (2013)noted that the Kelpak (a liquid seaweed concentrate made from the kelp Ecklonia maxima) is most effective in neutral $\mathrm{pHs}$, it can be used to promote plant grow that low $\mathrm{pH}$ and water stress conditions.

The treatment $\mathrm{T}_{2}$ (soil application of SWE @ 25kg/ha) had the numerically higher amount of available nitrogen (259 kg/ha), which was on par with $\mathrm{T}_{1}(253 \mathrm{~kg} / \mathrm{ha})$ and

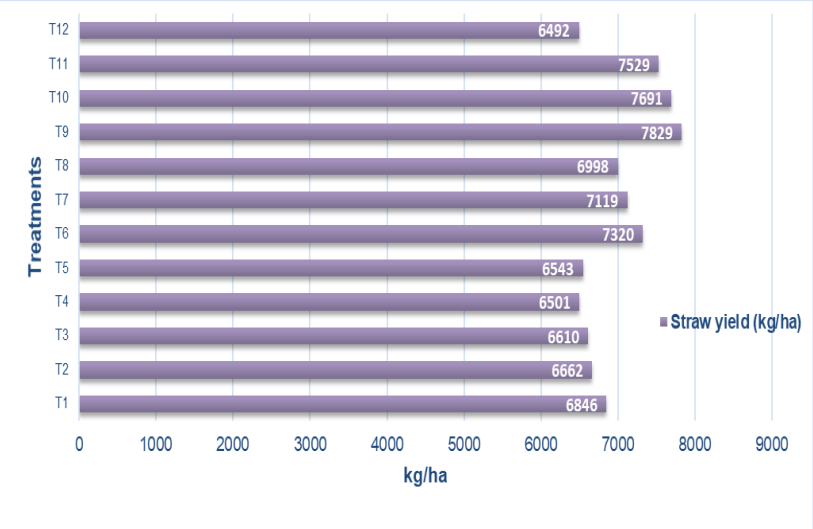

Fig 2. Straw yield in respective treatments expressed in $\mathrm{kgha}^{-1}$ 
$\mathrm{T}_{3}(252 \mathrm{~kg} / \mathrm{ha})$ and lower value was recorded under $\mathrm{T}_{12}$ (216 kg/ha) which was on par with $\mathrm{T}_{4}(218 \mathrm{~kg} / \mathrm{ha})$ and $\mathrm{T}_{5}$ (215 kg/ha) (Fig 3). The high value of available phosphorus $\left(42 \mathrm{~kg} / \mathrm{ha}\right.$ ) had registered under $\mathrm{T}_{2}$ (soil application of SWE @ 25kg/ha) followed by $T_{1}$ (40 kg/ha) which was on par with $\mathrm{T}_{3}(40 \mathrm{~kg} / \mathrm{ha})$ and least was observed under $\mathrm{T}_{12}$ (31 kg/ha) which was on par with $\mathrm{T}_{4}$ (32 kg/ha) (Fig 4). The amount of available potassium was numerically higher under $\mathrm{T}_{2}(170 \mathrm{~kg} / \mathrm{ha})$, which was on par with $T_{1}(168 \mathrm{~kg} / \mathrm{ha})$ and $T_{3}(169 \mathrm{~kg} / \mathrm{ha})$ and the least was recorded in $\mathrm{T}_{12}(144 \mathrm{~kg} / \mathrm{ha})$ which was on par with $T_{4}(146 \mathrm{~kg} / \mathrm{ha})$ and $T_{5}(146 \mathrm{~kg} / \mathrm{ha})(\mathrm{Fig} 3)$. A similar result was reported by Pramanick et al. (2014) in rice wih the application of seaweed extract @ 15\% released more plant nutrients, especially nitrates, ammonium \& phosphates into the soil, thereby increasing uptake of plant nutrients in sandy clay loam soil of BCKV, West Bengal. Singh et al. (2015) reported that the rice fertilized with $100 \%$ RDF produced higher nitrogen, phosphorus, potassium and sulphur uptake in grain and straw than $50 \%$ recommended fertilizer.

The high value of Exchangeable Calcium $\left(27.7 \mathrm{meq} / 100 \mathrm{~g}\right.$ ) was registered under $\mathrm{T}_{2}$ (soil application of SWE @ 25kg/ha) followed by $T_{1}(24.2$ meq/100g) which was on par with $\mathrm{T}_{3} \quad(21.9 \mathrm{meq} / 100 \mathrm{~g})$ and lower value was recorded under $T_{12}$ (15.9 meq/100g) which was on par with $\mathrm{T}_{4}(16.8 \mathrm{meq} / 100 \mathrm{~g})$ and $\mathrm{T}_{5}(17.2 \mathrm{meq} / 100 \mathrm{~g})$. Exchangeable magnesium $\left(5.5 \mathrm{meq} / 100 \mathrm{~g}\right.$ ) was recorded higher under $\mathrm{T}_{2}$ (soil application of SWE @ 25kg/ha) followed by $T_{1} \quad(4.9$ meq/100g) which was on par with $\mathrm{T}_{3}(4.4 \mathrm{meq} / 100 \mathrm{~g})$ and least was recorded under $T_{12}(3.2 \mathrm{meq} / 100 \mathrm{~g})$ which was on par with $\mathrm{T}_{4}(3.4 \mathrm{meq} / 100 \mathrm{~g})$ and $\mathrm{T}_{5}$ (3.4meq/100g) (Table 5). The amount of available Sulphur was higher in $T_{2}(18.2 \mathrm{mg} / \mathrm{kg})$ followed by $T_{1}(17.3$ $\mathrm{mg} / \mathrm{kg})$ which was on par with $\mathrm{T}_{3}(15.9 \mathrm{mg} / \mathrm{kg})$ and the treatment $T_{12}(10.1 \mathrm{mg} / \mathrm{kg})$ recorded a lower amount of available Sulphur (Table 7). Similar findings by Ghosh et al. (2020) reported for blackgram in sandy loam soil of the red and lateritic belt of West Bengal with the application of seaweed @ 15\% Kappaphycus + RDF, resulting in higher availability and absorption of inorganic elements such as $\mathrm{Ca}, \mathrm{Na}, \mathrm{K}, \mathrm{Mg}, \mathrm{N}, \mathrm{Cu}, \mathrm{Zn}$ etc.

The treatment $T_{2}$ (soil application of SWE @ 25kg/ha) recorded higher amount of available zinc (1.17ppm) followed by $T_{1}$ (1.08 ppm) which was on par with $T_{3}$ (1.04 ppm) and less amount of available zinc (0.32 ppm) was reported in $\mathrm{T}_{12}$. The amount of available $\mathrm{Fe}$ was showed a higher value under $\mathrm{T}_{2}$ (33.82ppm), which was on par with $T_{1}$ (31.84 ppm) and least was recorded under $\mathrm{T}_{12}$ (13.67 ppm), which was on par with $\mathrm{T}_{4}$ (14.74ppm) (Table 7). A higher amount of available $\mathrm{Cu}$ was observed under $T_{2}$ (1.61ppm) followed by $T_{1}(1.44$ ppm) which was on par with $\mathrm{T}_{3}(1.37 \mathrm{ppm})$ and a lower value was reported under $\mathrm{T}_{12}(0.67 \mathrm{ppm})$. The available

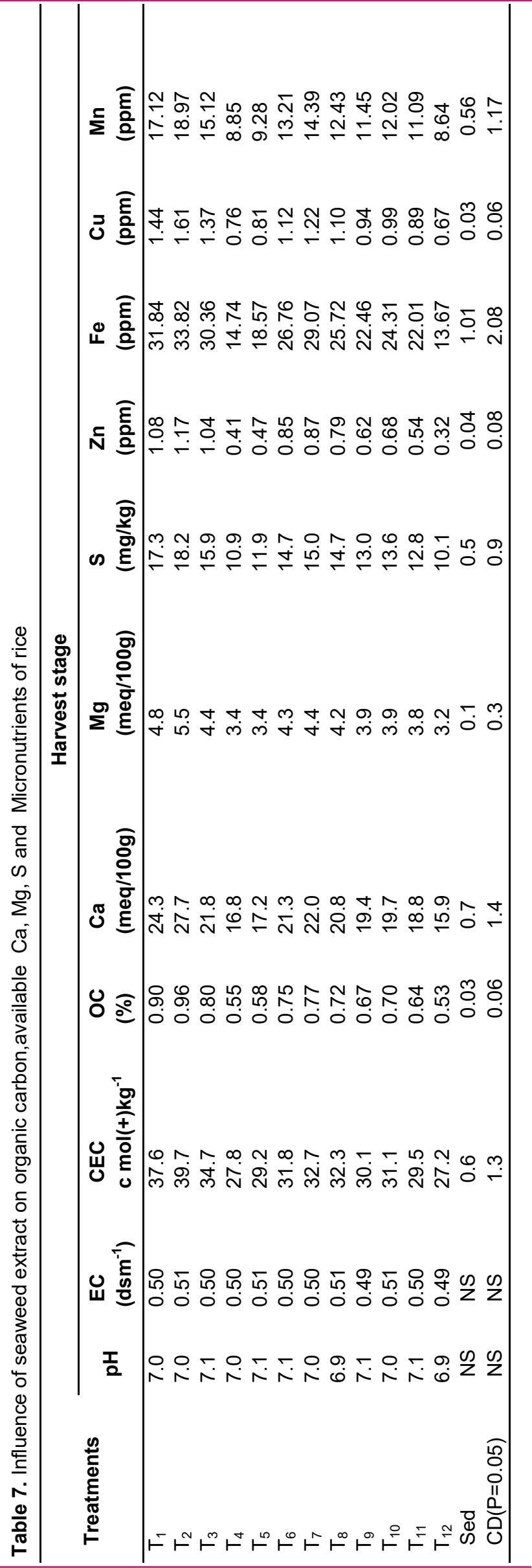




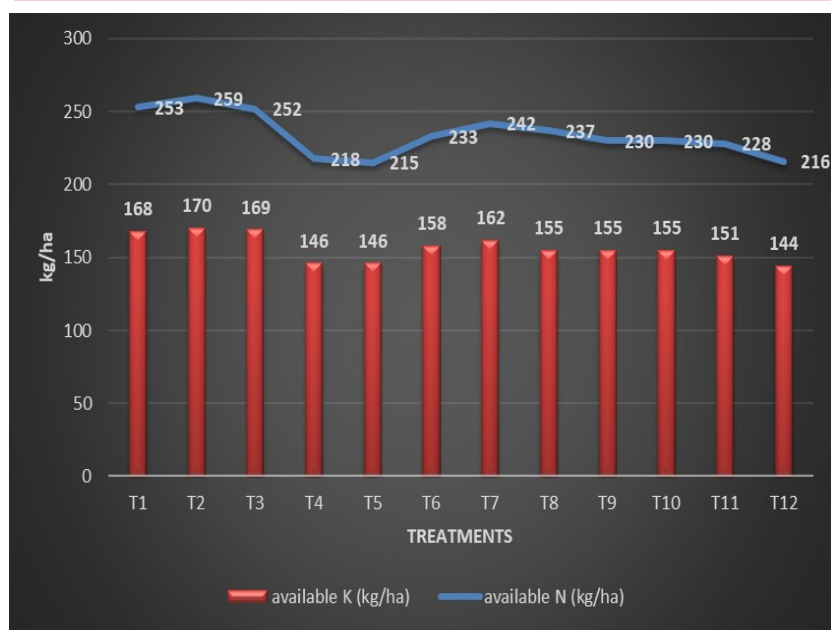

Fig 3. Nutrient uptake of nitrogen and potassium in various treatments expressed in $\mathrm{kgha}^{-1}$

Mn (18.97 ppm) was higher under $\mathrm{T}_{2}$ (18.97 ppm) followed by $T_{1}(17.12 \mathrm{ppm})$ and the least was recorded under $\mathrm{T}_{12}(8.64 \mathrm{ppm})$, which was on par with $\mathrm{T}_{4}(8.85$ ppm)and $T_{5}$ (9.28 ppm) (Table 7). Layeket al.(2017) reported that in clay loam soil of eastern Himalayas, the application of $K$. alvarezii ( $\mathrm{K}$ sap) or Gracilaria edulis (G sap) at $10 \%$ along with $100 \%$ RDF increased micro-nutrient ( $\mathrm{Fe}, \mathrm{Cu}, \mathrm{Mn}$ and $\mathrm{Zn})$ and protein content in rice. Pal et al.(2015) reported for maize that the foliar application of seaweed extract @ 15\% Gracilaria (G sap) along with RDF observed higher available nutrients viz., $\mathrm{N}, \mathrm{P}, \mathrm{K}, \mathrm{Ca}, \mathrm{Mg}$ and micronutrients. Nayak et al.(2020) showed that in rice the application of $100 \%$ RDF + Biozyme granule @ 15 kg/ha observed higher organic carbon, available nitrogen, phosphorus and potassium in sandy loam soil of BCKV, West Bengal. Raverkaret al. (2016) noted that in green gram, the foliar spraying of seaweed saps @ $10 \%$ Kappaphycus sap along with RDF increased the grain nitrogen content, protein content and inorganic elements viz., $\mathrm{Ca}, \mathrm{Na}, \mathrm{K}, \mathrm{Mg}, \mathrm{Zn}$. Bhattacharya et al. (2020) described that the seaweed biorefinery made a great effort towards improved utilization of biomass with a low water footprint and minimal effluent discharge.

Though there is research available on the role of seaweed on different crops, the information regarding seaweed on improving the rice crop yield and soil quality is lagging. The present study mainly focused on the Cauvery delta zone because more than $90 \%$ of the area is under rice cultivation and the nature of the soil was heavy clayey textured. The soil fertility was getting declined due to continuous rice cultivation. So the seaweed application, one of the organic sources which boot the soil ecology and soil health in a most prominent way through the soil and foliar on rice productivity and soil fertility in this Cauvery delta zone, is highly essential.

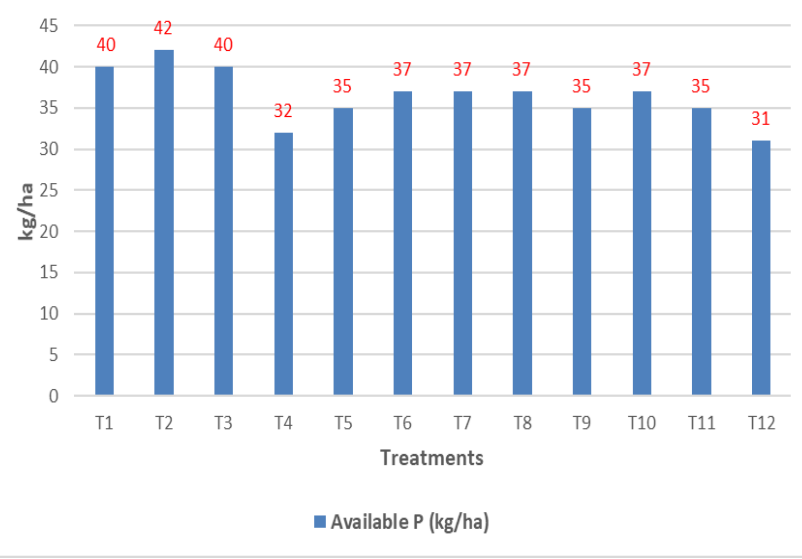

Fig 4. Phosphorus uptake in various treatments expressed in $\mathrm{kg} \mathrm{ha}^{-1}$

\section{Conclusion}

The study on the influence of the seaweed extract $K$. alvareziion on the rice crop (O. sativa) var. ADT53 yield and soil fertility concluded that the soil application of seaweed extract @ 12.5 kg/ha along with the foliar spraying of seaweed extract liquid @0.5\% twice at tillering and panicle initiation stage had higher crop growth parameters like plant height, LAI, DMP \& SPAD and yield parameters viz., no of grains/panicle, panicle length, no of productive tillers $/ \mathrm{m}^{2}$, grain yield and straw yield. The rice yield was also increased by $18-20 \%$ over the recommended dose of fertilizer. However, the soil application of seaweed extract @ $25 \mathrm{~kg} / \mathrm{ha}$ was found to be superior in improving the available nutrients like N, P, K, Ca, Mg, S and micronutrients. The recommendation emanated from the study for the deltaic farmers is the soil application of seaweed extract along with foliar spray @ $0.5 \%$ twice at tillering and panicle initiation stage for enhancing the rice productivity and soil fertility.

\section{Conflict of interest}

The authors declare that they have no conflict of interest.

\section{REFERENCES}

1. Arun, M.N., Kumar, R.M., Nori,S., Singh,A., Tuti,M.D., Srinivas, D., Venkatanna, B., Surekha, K., Padmavathi, C.h.\& Prasad, M.S. (2019). Effect of seaweed extract as biostimulant on crop growth and yield in rice (oryza sativa L.) under transplanted condition. Journal of Rice Research, 12(2),45-49.

2. Arioli,T., Scott, W., Mattner, C., Pia, C. \& Winberg. (2015). Applications of seaweed extracts in Australian agriculture: past, present and future.International Society for Applied Phycology,27,2007-2015. https://doi.org/10.1007/s10811015-0574-9Anil, K., Yakadri, M. \&Jayasree, G. (2014). Influence of Nitrogen Levels and time of application on growth parameters of aerobic rice. International Journal of 
Plant Animal and Environmental Sciences, 4(3), 231 . 234.

3. Arthur,G.D., Aremu,A.O., Moyo,M., Stirk,W.A. \&Staden,J. (2013). Growth-promoting effects of a seaweed concentrate at various $\mathrm{pH}$ and water hardness conditions : research article. South African Journal of Science,109(11),1 -6. https://hdl.handle.net/10520/EJC145687

4. Bhattacharya,S., Baghel,R.S., Suthar,P., Gajaria,K.T., Anil,A. \& Reddy, C.R.K. (2020). Seaweed biorefinery: A sustainable process for valorizing the biomass of brown seaweed.Journal of Cleaner Production, 263, 121359. https://doi.org/10.1016/j.jclepro.2020.121359

5. Dilavarnaik, S., Basavaraja, P.K., Yogendra, N.D. \& Ghosh, A. (2017). Influence of Seaweed Saps on Germination, Growth and Yield of Hybrid Maize under Cauvery Command of Karnataka, India. International Journal of Current Microbiology and Applied Sciences, 6(9), 10471056. https://doi.org/10.20546/ijcmas.2017.609.126

6. Dwivedi,S.K., Meshram,M.K., Pal,A., Pandey,N. \&Ghosh.A. (2014). Impact of natural organic fertilizer (seaweed saps) on productivity and nutrient status of blackgram (Phaseolus mungo I.). The Bioscan, 9(4), 15351539.

7. Domínguez,B.D., Carmona,H.G., Moyo,M., Stirk,W. \& St aden,J (2014). Plant growth promoting activity of seaweed liquid extracts produced from Macrocystis pyrifera under different $\mathrm{pH}$ and temperature conditions. Journal of Applied Phycology, 26, 2203-2210.https:// doi.org/10.1007/s10811-014-0237-2

8. Deshmukh, P. S.\&Phonde, D. B.(2013). Effect of seaweed extract on growth, yield and quality of sugarcane. International Journal of Agricultural Sciences,9(2), 750753. URL : http://www.researchjournal.co.in/onli...

9. Dogra,B.S., \& Mandradia, R.K. (2012). Effect of seaweed extract on growth and yield of onion. International Journal of Farm Sciences, 2(1), 59-64.

10. Evenni, P.S.L., Castro,W., Allisson,J., Castro,G., Nascimento, S., Pinheiro,S.D., Florentin,Q.D.K., Luciana, G., Soriano,M.E., Araujo,M.R.\&Leite,E.L. (2015). Effect of galactofucan sulfate of a brown seaweed on induced hepatotoxicity in rats, sodium pentobarbital-induced sleep, and anti-inflammatory activity. Journal of Applied Phycology, 28, 2005-2017. https://doi.org/10.1007/s10811-0150698-y

11. Ghosh, A., Shankar,T., Malik,G.C., Banerjee,M. \& Ghosh,A. (2020). Effect of seaweed extracts on the growth, yield and nutrient uptake of black gram (Vigna mungo L.) in the red and lateritic belt of West Bengal. International Journal of Chemical Studies, 8(3), 799-802. https://doi.org/10.22271/chemi.2020.v8.i3j.9300

12. Grassinin, P., Van Bussel, L.G.J., P., Van Mart, J., Wolf, J., Claessens, L., Yang, H., Boogaard, H., De Groot, H., Van Ittersum, M.K. \&Cassman, K.G. (2015). How good is good enough? Data requirements for reliable crop yield simulations and yield gap analysis. Field Crops Research, 177, 49-63.

13. Hussain,H.I., Kasinadhuni,N. \&Arioli,T. (2021). The effect of seaweed extract on tomato plant growth, productivity and soil. Journal of Applied Phycology,33,13051314.https://doi.org/10.1007/s10811-021-02387-2

14. Haider,M.W., Ayyub,C.M., Pervez,M.A., Asad,H.U., Manan,A., Raza,S.A. \&Ashraf,I. (2012). Impact of foliar appli- cation of seaweed extract on growth, yield and quality of potato (Solanum tuberosum L.).Plant Soil and Environment, 31(2), 157-162.

15. Iswarya, S., Latha, K.R. \& Srinivasan, K. (2019). Evaluation of seaweed extract on growth determinants, yield and biochemical parameters of greengram (Vigna radiata). Journal of Pharmacognosy and Phytochemistry, 8(3), 1861-1864.

16. Jithesh, M.N., Owen,S.D., Wally., Manfield, I., Critchley, A.T., Hiltz,I. \&Prithiviraj, B. (2012). Analysis of Seaweed Extract-induced Transcriptome Leads to Identification of a Negative Regulator of Salt Tolerance in Arabidopsis. American society of Horticultural science,47(6),704-709. https://doi.org/10.21273/HORTSCI.47.6.704

17. Kumar, R., Pyare,R., Singh,U.P., Kumar,Y., Singh,Y.K. \& Maurya,R.N. (2020). Studies about the soil microbial populations, root development and economics of paddy as influenced by sea weed extract (Ascophyllumnodosum). Journal of Pharmacognosy and Phytochemistry, 9(5), 592594.

18. Layek, J., Das, A., Idapuganti, R. G., Sarkar, D., Ghosh, A., Zodape, S.T., Lal,R., Yadav,G.S., Panwar,A.S., Ngachan,S. \& Meena.R.S. (2017). Seaweed extract as organic bio-stimulant improves productivity and quality of rice in eastern Himalayas. Journal of Applied Phycology,30,547558.https://doi.org/10.1007/s10811-017-1225-0

19. Leindah Devi, N. \& Mani. S. (2015).Effect of seaweed saps Kappaphycus alvarezii and Gracilaria on Growth, Yield and Quality of Rice. Indian Journal of Science and Technology, 8(19),1-6.

20. Manea,A.I.\&Abbas,K.A.U (2018). Influence of Seaweed Extract, Organic and Inorganic Fertilizer on Growth and Yield Broccoli. International journal of vegetable science, 24(6), 550-556. https://doi.org/10.1080/19315260.2 018.1 446205

21. Mirparsa, T., Ganjali, H. R.\& Dahmardeh, M. (2016). The effect of bio fertilizers on yield and yield components of sunflower oil seed and nut. International Journal of Agriculture and Biosciences,5 (1),46-49. http://www.ijagbio.c om/.../46-49.pdf

22. Mathur,C., Rai,S., Sase,N., Krish, S. \&Jayasri,M.A. (2015). Enteromorpha intestinalis Derived Seaweed Liquid Fertilizers as Prospective Biostimulant for Glycine max. Brazilian Archives of Biology and Technology, 58 (6),813-82 0.https://doi.org/10.1590/S1516-89132015060 304

23. Nayak,P., Biswas,S. \& Dutta,D. (2020). Effect of seaweed extracts on growth, yield and economics of kharif rice (Oryza sativa L.). Journal of Pharmacognosy and Phytochemistry, 9(3), 247-253. https://doi.org/10.22271/ phyto.2020.v9.i3d.11269

24. Nabti, E., Sahnoune, M., Ghoul, M., Fischer, D., Hofmann, A., Rothballer, M.,Schmid,M. \& Hartmann,A. (2010). Restoration of Growth of Durum Wheat (Triticum durum var. waha) Under Saline Conditions Due to Inoculation with the Rhizosphere Bacterium Azospirillumbrasilense $\mathrm{NH}$ and Extracts of the Marine Alga Ulva lactuca. Journal of Plant Growth Regulation, 29,6-22. https://doi.org/10.1007/s0034 4-009-9107-6

25. Olsen,S.R.,Cole,C.V.,,Watanable,F.S. \& Dean, L.A. (1954). Estimation of available phosphorus in soils by extraction wioth sodium bicarbonate. Washington, DC: US Department of Agriculture. Circular, 939, 19. 
26. Pramanick, B., Brahmachari, K., Mahapatra, B.S., Ghosh, A., Ghosh, D. \& Kar, S. (2017). Growth, yield and quality improvement of potato tubers through the application of seaweed sap derived from the marine alga Kappaphycus alvarezii.Journal of Applied Phycology, 29, 3253-3260. https://doi.org/10.1007/s10811-017-1189-0

27. Pacholczak,A., Nowakowska,K.\& Pietkiewicz, S. (2016). The Effects of Synthetic Auxin and a Seaweed-based Biostimulator on Physiological Aspects of Rhizogenesis in Ninebark Stem Cuttings. Notulae. Botanicae. Horti. Agrobotanici. Cluj-Napoca, 44 (1), 85-91. https:// doi.org/10.15835/nbha44110061

28. Pal, A., Dwivedi,S.K., Maurya,P.K. \& Kanwar,P. (2015). Effect of seaweed saps on growth, yield, nutrient uptake and economic improvement of maize (sweet corn). Journal of Applied and Natural science,7(2), 970-975https:// doi.org/10.31018/jans.v7i2.716

29. Pramanick, B., Bramachari, K., Ghosh, A. \&Zodape, S.T. (2014). Effect of seaweed saps on growth and yield improvement of transplanted rice in old alluvial soil of West Bengal. Bangladesh Journal of Botany, 43(1), 53-58. https://doi.org/10.3329/bjb.v43i1.19746

30. Pramanick, B., Brahmachari, K. \& Ghosh, A. (2013). Effect of seaweed saps on growth and yield improvement of green gram. African Journal of Agricultural Research, 13 (8), 1180-1186. https://doi.org/10.5897/AJAR12.1894

31. Partani, T. (2013). Determination of effect of different rates of seaweed extract on growth and performance of corn (Sc704) in Gorgan. International Journal of Agriculture and Crop Sciences (IJACS),6(4), 219-224. URL : http://ijagcs.com/.../219-224.pdf

32. Rathinapriyaa, P., Satish, L., Pandiana. S., Rameshkumara, R., Balasangeethaa, M., Rakkammal, K. \&Ramesh,M. (2020). Effects of liquid seaweed extracts in improving the agronomic performance of foxtail millet. Journal of plant nutrition,1-20. https://doi.org/10.1080/01904167.2020.17 99002

33. Raghunandan, B.L.,Vyas,R.V.,Patel,H.K. \& Jhala,Y.K. (2019). Perspectives of Seaweed as Organic Fertilizer in Agriculture. Soil Fertility Management for Sustainable Development, 267-289. DOI: 10.1007/978-981-13-5904 $-0 \quad 13$

34. Raverkar, K.P., Navneet, P., Ramesh, C., Swati, C., Zodape, S.T. \& Ghosh, A. (2016). Impact of foliar applica- tion of seaweed saps on yield, nodulation and nutritional quality in green gram (Vigna radiata L).Legume Research,39(2), 315-318. 10.18805/Ir.v39i2.9535

35. Rathore, S.S., Chaudhary, D.R., Boricha, G.N., Ghosh, A., Bhatt, B.P., Zodape, S.T. \&Patolia, J.S. (2009).Effect of seaweed extract on the growth, yield and nutrient uptake of soybean (Glycine max) under rainfed conditions. South African Journal of Botany, 75, 351-355. https:// doi.org/10.1016/j.sajb.2008.10.009

36. Rayorath ,P., Khan, W., Ravishankar, P., Shawna, L.M., Roumiana, S., Simon, D.H., Alan, T.C. \&Balakrishan, P. (2008). Extract of the brown seaweed Ascophyllum nodosum induce gibberellic acid (GA3) - independent amylase activity in barley. Journal of Plant Growth Regulators, 27,370-379. https://doi.org/10.1007/s00344-0089063-6

37. Shimaa, M.E., ShafaySamh,S., Mostafa, A. \& Sheeekh, M.E. (2016). Antimicrobial activity of some species from Red sea, against multidrug resistant bacteria. The Egyptian Journal of Aquatic Research, 42 (1), 65-74. https:// doi.org/10.1016/j.ejar.2015.11.006

38. Singh, S.K., Thakur, R., Singh, M. K., Singh, C.S. \&Pal,S.K. (2015). Effect of fertilizer level and seaweed sap on productivity and profitability of rice (Oryza sativa). Indian Journal of Agronomy, 60(3), 420-425.

39. Sunarpi,S., Juprl,A., Kurnianingsih,R., Julisaniah,N.I. \&Nikmatullah,A.(2011). Effect of seaweed extracts on growth and yield of rice plants. Asian Journal of Tropical Biotechnology,8(1),1-6.

40. Selvaraj, R., Selvi, M. \&Shakila, P. (2004). Effect of seaweed liquid fertilizer on Abelmoschus esculentus (L). Moench and Lycopersicon lycopersicum Mill. Seaweed Resource Utilisation, 26, 121-123.

41. Van Bussel, L.G.J., Grassini, P., Van Mart, J., Wolf, J., Claessens, L., Yang, H., Boogaard, H., De Groot, H., Saito, K., Cassman, K.G. \& Van Ittersum, M.K. (2015). From fields to atlas: Upscaling of location specific yield gap estimates. Field Crops Research, 177, 98-108.

42. Whapham, C.A., Blunden, G., Jenkins, T. \& Hankins, S.D. (1993). Significance of betaines in the increased chlorophyll content of plants treated with seaweed extract. Journal of Applied Phycology, 5, 231-234. https:// doi.org/10.1007/BF00004023 